\title{
Nitric Oxide
}

National Cancer Institute

\section{Source}

National Cancer Institute. Nitric Oxide. NCI Thesaurus. Code C695.

An unstable free-radical gas which reacts rapidly with oxygen to form nitrogen oxides.

Water soluble, NO is produced normally in numerous tissues and is considered to be a mediator of cell-to cell communication; it functions in numerous processes including vasodilation, inflammation, and neurotransmission. ( $\mathrm{NCI04)}$ 